\title{
Analisis Kepuasaan Konsumen Pada Produk Mobil Di PT. Hasjrat Abadi Cabang Manado (Dealer Toyota)
}

\author{
Stefanly Wahongan \\ Tinneke M. Tumbel \\ Olivia F. C. Walangitan \\ Jurusan Ilmu Administrasi Program Studi Ilmu Administrasi Bisnis \\ Fakultas Ilmu Sosial dan Politik Universitas Sam Ratulangi \\ Email :wahonganstefan@gmail.com
}

\begin{abstract}
The purpose of this study was to determine customer satisfaction in the products of PT. Hasjrat Abadi branch Manado. This study uses interview data collection techniques and observations with qualitative descriptive data analysis techniques. The focus of this study is customer satisfaction with the services of PT. Hasjrat Abadi branch of Manado measured from several aspects: 1) Consumer satisfaction in the process of car purchase administration, 2) Consumer satisfaction with the quality of products purchased, 3) Consumer satisfaction with response from officers regarding Consumer complaints regarding car disturbances or technical problems, 4) Customer satisfaction with handling problems or technical problems of the car. Results of the study indicate that administrative procedures at the time of product purchase are still lacking. Likewise with customer satisfaction with the quality of the vehicle during use. Many complained that some items from the car products purchased were still lacking. Or not according to what was promoted. Furthermore, some customers say that the company is less alert and responsive to complaints submitted by customers on technical matters of The the products purchased. The latter is also carried out that repair services for damage experienced in purchased car products are still not satisfactory. In the sense that the improvements carried out have not been maximized.
\end{abstract}

Keywords: Customer Satisfaction, Administrative Procedure, Product Technical Problems, Response to Customer Complaints, Handling Or Technical Services.

\section{Pendahuluan}

Pada dasarnya keberhasilan suatu perusahaan di dalam memproduksi dan memasarkan produknya sangat ditentukan oleh ketetapan strategi yang dipakai perusahaan. Khusus dalam industri otomotif, penerapan kebijakan strategi produk adalah suatu pilihan strategi yang tepat, sebagai rangkaian usaha memaksimalkan kepuasan Konsumen sasaran.
Kebijakan strategi produk adalah suatu rangkaian proses kegiatan yang berlangsung secara berkesinambungan dan terus menerus di dalam menciptakan, mengembangkan dan menyempurnakan produk sehingga dapat diterima Konsumen sasaran (Kotler dan Armstrong, 2016).

PT. Hasjrat Abadi Cabang Manado bergerak dalm industri otomotif khususnya pemasaran dan penjualan berbagai produk Toyota yang menghasilkan beberapa jenis 
produknya yang berbeda. Toyota mrupakan perusahaan yang bergerak di bidang industri otomotif. Brand produk ini telah mendunia dan dikenal sejak puluhan tahun lalu. Penjualan produk ini pun menempati ranking pertama di tingkat nasional untuk semua jenis produk otomotif. Namun demikian ada beberapa pengeluhan yang disampaikan oleh Konsumen terhadap pelayanan PT. Hasjrat Abadi Cabang Manado. Beberapa keluhan tersebut di antaranya : produk yang dibeli tidak sama dengan yang dipromosikan (beberapa komponen kendaraan bermasalah), mendapatkan pelayanan yang kurang baik (Konsumen merasa tidak dihargai, lamban dalam pelayanan, kesalahpahaman dalam komunikasi), petugas yang tidak berkompeten dan lainlain.

Dalam menghadapi persaingan yang semakin ketat, suatu perusahaan perlu memahami perilaku konsumen agar perusahaan mampu bersaing dengan perusahaan lainnya. Pemahaman tentang perilaku konsumen itu mempunyai arti penting karena sesungguhnya semua kegiatan perusahaan ditujukan untuk memberikan kepuasan kepada konsumen (Adi, 2010). Perusahaan tentunya sadar bahwa dalam era globalisasi pemasaran merupakan kunci dan faktor penting untuk mencapai sukses. Pemasaran memusatkan perhatian pada konsumen karena dengan tercapainya kebutuhan dan kepuasan konsumen akan memberikan keuntungan yang layak dalam jangka panjang. Tujuan kegiatan pemasaran itu sendiri adalah mempengaruhi konsumen untuk membeli barang dan jasa perusahaan pada saat itu yang mereka butuhkan (Sunarto, 2010).

Hal inilah yang mendasari penulis untuk mengangkat masalah ini sebagai bahan penelitian dalam rangka penulisan skripsi yang berjudul : "Kepuasan Konsumen Terhadap Produk Mobil Pada PT. Hasjrat Abadi Cabang Manado"

\section{Konsep Manajemen Pemasaran}

Konsep inti pemasaran adalah pertukaran nilai-nilai antara dua pihak dimana nilai-nilai yang dibutuhkan tersebut tidak terbatas pada barang, jasa dan uang tetapi juga mencakup sumbersumber lain seperti waktu, energi dan perasaan.

\section{Konsep Kepuasan Konsumen}

Tjiptono menandaskan bahwa kepuasan Konsumen adalah tingkat perasaan seseorang (Konsumen) setelah membandingkan dengan kinerja yang ia rasakan, dibandingkan dengan harapannya. Berdasarkan definisi tersebut, maka dapat dikatakan bahwa tingkat kepuasan Konsumen merupakan fungsi dari harapan Konsumen dengan kinerja yang dirasakan.

\section{Metode Penelitian}

Penelitian ini menggunakan metode kualitatif. Menurut Sugiono (2012), penelitian kualitatif itu berakar pada latar belakang alamiah sebagai keutuhan, mengandalkan manusia sebagai alat penelitian, menganalisis data secara 
induktif, bersifat deskriptif, lebih mementingkan proses daripada hasil, dan membatasi studi dengan fokus.

Penggunaan metode penelitian kualitatif dalam penelitian ini dimaksudkan untuk memperoleh jawaban atas permasalahan yang berhubungan dengan proses implementasi pelayanan publik yang diberikan oleh PT. Hasjrat Abadi cabang Manado. Lokasi penelitian di PT. Hasjrat Abadi Cabang Manado, khususnya yang berada di kantor cabang Jalan Sudirman Komo Luar Manado.

Fokus penelitian ini adalah berkaitan dengan pelayanan yang diberikan oleh PT. Hasjrat Abadi Cabang Manado terkait dengan produk-produk yang dijual oleh perusahaan dan dibeli oleh para Konsumen. Kepuasan Konsumen diukur dari beberapa aspek : 1) kepuasan Konsumen pada proses administrasi pembelian mobil, 2) kepuasan Konsumen terhadap kualitas produk yang dibeli, 3) kepuasan Konsumen terhadap respon dari petugas terkait keluhan-keluhan Konsumen atas gangguan atau masalah teknis mobil, 4) kepuasan Konsumen terhadap penanganan atas masalah atau gangguan teknis mobil.

Berdasarkan metode penelitian, maka teknik pengumpulan data dilakukan dengan wawancara langsung dan observasi lapangan. Pedoman atau format wawancara yang ada hanya dibuat sebagai bingkai wawancara agar tidak menyimpang jauh dari maksud penelitian. Ini dimaksudkan dengan harapan agar para informan memberikan keterangan dan pendapatnya secara bebas tentang masalah yang sedang diteliti atau dapat disebut wawancara terbuka (open ended interview).

\section{Hasil Penelitian}

Untuk mengetahui kepuasan Konsumen pada produk di PT. Hasjrat Abadi Cabang Manado, maka telah ditentukan beberapa orang sebagai informan atau responden penelitian. Responden penelitian diambil 4 orang dari manajemen perusahaan (satu orang kepala cabang, satu orang manajer pemasaran dan 2 orang karyawan di bagian penjualan). Selain itu diambil juga Konsumen sebanyak 10 orang untuk melihat bagaimana kepuasan Konsumen terhadap produk yang dibeli di PT. Hasjrat Abadi Cabang Manado. Terhadap 14 orang informan ini telah dilakukan wawancara untuk mendapatkan informasi-informasi yang terkait dengan permasalahan penelitian. Setelah hasil wawancara dengan para informan penelitian, maka berikut ini akan dirangkum hasil wawancara tersebut yang terkait dengan kepuasan Konsumen:

\section{a. Kepuasan Konsumen terhadap prosedur administrasi}

Pada aspek ini pemenuhan administrasi harus diikuti oleh Konsumen untuk memiliki kendaraan yang 
diinginkannya. Berkas-berkas dokumen sebagai persyaratan dipersiapkan oleh pihak perusahaan dan juga oleh Konsumen.

Dari wawancara yang dilakukan dapat diketahui bahwa pada tahap ini semuanya berjalan relatif lancar. Hal ini bisa dipahami karena perusahaan berkepentingan agar Konsumen melakukan transaksi pembelian kendaraan. Oleh sebab itu semua fasilitas atau sarana dan prasarana yang ada diperhatikan dengan baik oleh perusahaan. Responden mengakui bahwa karyawan yang menangani administrasi ini perlu ada perbaikan-perbaikan sehingga dapat lebih menguasai dan memahami apa yang menjadi tugas dan tanggung jawabnya.

\section{b. Kepuasan Konsumen terhadap kualitas kendaraan yang dibeli}

Aspek ini berkaitan dengan produk yang dibeli. Pada bagian ini Konsumen langsung mengalami dan merasakan produk yang telah dibelinya selama beraktivitas sehari-hari dengan menggunakan kendaraan ini. Sebagian besar Konsumen mengakui bahwa ada beberapa bagian kendaraan yang bermasalah. Mereka mengakui bahwa spesifikasi kendaraan belum sepenuhnya sesuai dengan yang ditawarkan. Dalam artian bahwa ada beberapa bagian kendaraan yang bermasalah yang perlu penanganan teknis segera.

\section{c. Kepuasan Konsumen terhadap penanganan petugas atas keluhan- keluhan Konsumen}

Petugas atau karyawan pada PT. Hasjrat Abadi harus mampu memahami secara cepat terhadap apa yang menjadi masalah kebutuhan pelayanan yang diinginkan oleh Konsumen. Dalam kaitan ini perlu diperhatikan agar semua unsur pelayanan Konsumen di lingkungan PT. Hasjrat Abadi memliki tingkat responsvitas yang baik dan cepat. Responden mengatakan bahwa kenyataannya seringkali keluhan-keluhan yang disampaikan oleh Konsumen kurang ditanggapi oleh petugas pelayanan.

\section{d. Kepuasan Konsumen terhadap perbaikan teknis atau pelayanan pasca penjualan}

Harus juga diperhatikan oleh semua unsur petugas pelayanan yang ada untuk memiliki sikap yang baik dan ramah terhadap semua Konsumen tanpa terkecuali. Kenyataannya Konsumen mendapati petugas yang tidak memahami unsur-unsur teknis dari kendaraan. Penanganan secara teknis ini memerlukan waktu yang cukup panjang. Mulai dari antrian masuk bengkel sampai mobil ditangani. Perbaikan-perbaikan yang dilakukan juga masih bermasalah di kemudian hari. Artinya kerusakan teknis 
yang diperbaiki muncul lagi di kemudian hari.

\section{Pembahasan}

Loyalitas Konsumen akan dapat dipertahankan apabila kepuasan Konsumen terpenuhi. Artinya ada kaitan erat antara strategi pemasaran yang dilakukan dengan kepuasan Konsumen. Secara sederhana dapat dikatakan bahwa kepuasan Konsumen hanya akan tercapai bila semua kebutuhan dan keinginan dari para Konsumen dapat terpenuhi. Konsumen merasa puas atas produk yang dibeli. Konsumen merasa puas atas pelayanan dari perusahaan. Konsumen merasa puas karena prosedur administrasi yang diberlakukan oleh perusahaan tidak berbelit-belit. Pada akhirnya Konsumen akan merasa puas jika semua keluhan terkait permasalahan yang ditemuinya dapat ditangani secara baik dan benar sesuai dengan prosedur yang berlaku.

Hasil penelitian memperlihatkan bahwa kepuasan Konsumen terhadap produk mobil di PT. Hasjrat Abadi Cabang Manado belum sepenuhnya terpenuhi. Dengan perkataan lain, perusahaan belum dapat memberikan pelayanan maksimal yang berujung pada kepuasan Konsumen. Pelayanan yang ada masih belum memenuhi harapan-harapan dari para Konsumen.

Beberapa aspek yang diteliti terkait dengan kepuasan Konsumen, yaitu : 1) kepuasan Konsumen terhadap prosedur administrasi pemilikan kendaraan/mobil; 2) Kepuasan Konsumen terhadap kendaraan setelah digunakan dalam kegiatan sehari-hari; 3) Kepuasan Konsumen dalam hal penyampaian keluhan-keluhan atas permasalahan yang dialaminya pada produk mobil yang dibelinya; 4) Kepuasan Konsumen terhadap perbaikan teknis atas kendaraan yang dimilikinya.

Hasil wawancara yang dilakukan dan selanjutnya telah dipaparkan pada bagian sebelumnya menunjukkan bahwa ke empat aspek yang diteliti ini masing-masing belum tertangani secara maksimal. Dalam artian masih ada kekurangan dan kelemahan yang perlu mendapat perhatian oleh pihak manajemen dan ditindaklanjuti dengan upaya-upaya perbaikan.

Seperti diungkapkan sebelumnya bahwa kepuasan Konsumen merupakan tujuan pelayanan dari setiap perusahaan. Oleh karena itu maka perlunya diperhatikan beberapa hal, di antaranya :

1. Konsep mendahulukan kepentingan Konsumen. Pelayanan yang berkualitas adalah pelayanan yang memuaskan Konsumen. Salah satu indikator adanya kepuasan Konsumen adalah tidak adanya keluhan dari Konsumen. Akan tetapi dalam prakteknya, keluhan-keluhan itu selalu ada. PT. Hasjrat Abadi sebagai perusahaan yang menjual produk- 
produk kendaraan wajib menanggapi dan menghadapi keluhan Konsumen tersebut untuk kepentingan dan kepuasan Konsumen. Untuk itu, pemberian pelayanan perlu mengetahui sumber-sumber keluhan Konsumen dan mengetahui cara-cara mengatasi keluhan tersebut;

2. Pelayanan dengan sepenuh hati. Pada hakekatnya Konsumen menginginkan pelayanan yang baik, cepat dan berkualitas. Ini merupakan falsafah dalam upaya memberikan pelayanan yang prima. Untuk itu, pihak perusahaan PT. Hasjrat Abadi Cabang Manado perlu lebih banyak belajar tentang kondisi Konsumen, agar dapat memberikan pelayanan dengan sepenuh hati dan dengan cara yang lebih baik di masa yang akan datang;

3. Budaya pelayanan prima. Pihak manajemen PT. Hasjrat Abadi Cabang Manado beserta seluruh karyawannya hendaknya memperhatikan budaya pelayanan prima ini. Menganggap pelayanan prima sebagai suatu budaya berarti melakukan kegiatan pelayanan sebagai suatu hal yang membanggakan dengan nilai luhur yang dijunjung tinggi. Budaya pelayanan prima adalah sebuah budaya yang kuat yang mewarnai sifat hubungan antara perusahaan sebagai pemberi pelayanan dengan Konsumennya dan dapat menjadi sarana yang sangat baik untuk memperoleh perhatian masyarakat dari perusahaan pemberi pelayanan. Budaya pelayanan prima dibentuk oleh sikap petugas atau karyawan dalam memberikan pelayanan;

4. Sikap pelayanan prima. Sikap pelayanan prima berarti pengabdian yang tulus terhadap bidang kerja dan yang paling utama adalah kebanggaan atas pekerjaan. Konsumen akan menilai perusahaan dari kesan pertama mereka dalam berinteraksi dengan orang-orang yang terlibat dalam perusahaan tersebut. Itulah sebabnya semua unsur yang terkait dalam perusahaan PT. Hasjrat Abadi perlu memperhatikan adanya sikap pelayanan prima ini;

Pelayanan prima sangat memperhatikan individu sebagai pribadi yang unik dan menarik. Setiap Konsumen memiliki sifat dan dapat membuat para petugas bahagia atau kecewa. Sentuhan pribadi mengarahkan para petugas pelayanan untuk berpikir bahwa memperlakukan orang lain sebagaimana memperlakukan diri sendiri perlu selalu dipraktekkan. Yang diutamakan dalam pelayanan prima bukanlah slogan-slogan untuk memberikan pelayanan terbaik bagi Konsumen, melainkan bentuk nyata pelayanan yang sebelumnya sudah diberikan dalam pelatihan-pelatihan dan dapat diterapkan pada saat praktek di 
lapangan, ketika berhubungan langsung dengan Konsumen. Terkait dengan masalah ini maka manajemen PT. Hasjrat Abadi Cabang Manado perlu melakukan upaya-upaya untuk meningkatkan kualitas setiap individu dalam perusahaan. Pendidikan dan pelatihan yang teratur dan tearah adalah langkah positif untuk meningkatkan pelayanan dalam memberikan kepuasan Konsumen.

Dengan menempatkan Konsumen dalam kedudukan yang terhormat, maka secara tidak langsung kita telah menghormati Konsumen. Namun demikian Sumarni dan Suprianto (2010) mengemukakan bahwa sistem dan strategi kualitas yang berfokus pada Konsumen dapat efektif, apabila kita memperhatikan dimensi perbaikan kualitas seperti : 1) ketepatan waktu pelayanan ; 2) akurasi pelayanan ; 3) kesopanan dan keramahan dalam memberikan pelayanan ; 4) tanggung jawab ; 5) kemudahan mendapatkan pelayanan ; 6) kenyamanan dalam memperoleh pelayanan, dan atribut pendukung lainnya.

\section{Kesimpulan}

Bertitik tolak dari hasil penelitian dan pembahasan yang dilakukan dapat disimpulkan beberapa hal, yaitu sebagai berikut :

Kepuasan Konsumen terhadap prosedur administrasi : Konsumen mengakui bahwa prosedur administrasi sudah sesuai .Pada aspek ini pemenuhan prosedur administrasi harus diikuti oleh Konsumen untuk memiliki kendaraan yang diinginkannya.

Kepuasan Konsumen terhadap kualitas kendaraan yang dibeli : Hasil penelitian membuktikan bahwa sebagian besar Konsumen mengakui bahwa ada beberapa bagian kendaraan yang bermasalah.

Kepuasan Konsumen terhadap penanganan petugas atas keluhan-keluhan Konsumen : Responden mengatakan bahwa seringkali keluhan-keluhan yang disampaikan oleh Konsumen kurang ditanggapi oleh petugas pelayanan. Mereka mengatakan bahwa meskipun semua keluhan diperhatikan tapi tindaklanjutnya tertunda.

Kepuasan Konsumen terhadap perbaikan teknis atau pelayanan pasca penjualan : Hasil penelitian memperlihatkan bahwa Konsumen mendapati petugas yang tidak memahami unsur-unsur teknis dari kendaraan. Penanganan secara teknis ini memerlukan waktu yang cukup panjang. Mulai dari antrian masuk bengkel sampai mobil ditangani. Perbaikan-perbaikan yang dilakukan juga masih bermasalah di kemudian hari. Artinya kerusakan teknis yang diperbaiki muncul lagi.

\section{Saran}

Untuk meningkatkan kepuasan konsumen terhadap prosedur administrasi 
hendaknya pihak manajemen perlu mengadakan evaluasi dalam rangka mempermudah prosedur administrasi. Dengan demikian secara administrasi, proses lebih sederhana dan konsumen juga puas karena prosedur pembelian kendaraan tidak berbelit-belit.

Pihak manajemen perusahaan hendaknya perlu melakukan pengecekan terakhir sebelum produk diserahkan kepada konsumen. Ini untuk menghindari hal-hal yang tidak diinginkan akibat produk tidak maksimal dari segi kualitas. Mungkin karena ada beberapa bagian kendaraan yang bermasalah.

Petugas hendaknya responsif atas setiap keluhan konsumen terhadap keluhan-keluhan yang disampaikan. Setidaknya petugas yang menangani bagian keluhan konsumen perlu memehami aspek teknis kendaraan.

Petugas-petugas teknik dan mekanik menguasai seluk-beluk kendaraan sehingga mampu mendeteksi gangguangangguan yang ada pada kendaraankendaraan yang dijual. Upaya peningkatan kualitas dari para teknisi hendaknya terus ditingkatkan.Di samping itu, pihak manajemen perusahaan perlu memperbaiki semua fasilitas atau sarana dan prasarana yang ada di perusahaan tersebut yang dapat memperlancar pelayanan Konsumen yang diberikan. Diharapkan nantinya semua Konsumen yang memerlukan pelayanan dapat merasakan kenyamanan dan kepuasan atas pelayanan yang diterimanya.

\section{Daftar Pustaka}

Nugroho Adi, 2010. Perilaku Konsumen. Studio Press Jakarta Timur.

Sugiono, 2012. Metode Penelitian Administrasi. Alfabet Bandung.

Sunarto, 2010. Perilaku Konsumen. Amus Yogyakarta.

Kotle P. dan Keller, K. L. 2016. Manajemen Pemasaran. Cetakan ke-15. Jakarta

Tjiptono, 2015. Strategi Pemasaran. Edisi Revisi.Penerbit CV. Andi Offset. Jogjakarta

Ahmad Khusaini. 2016. “Analisis Kualitas Pelayanan terhadap Kepuasan Konsumen." Jurnal Universitas Jogjakarta. 